\title{
Nilai-Nilai Moral dalam Novel Ayat-Ayat Cinta Karya Habiburrahman El Shirazy
}

\author{
Aris Wibowo $\bowtie$, Universitas PGRI Madiun \\ Aris Wuryantoro, Universitas PGRI Madiun \\ Sigit Ricahyono, Universitas PGRI Madiun \\ $\triangle$ ariswida20@gmail.com
}

\begin{abstract}
Abstrak: Penelitian ini menggunakan metode deskriptif analisis. Sedangkan tujuan yang hendak dicapai adalah mendekripsilan dan menganalisis nilai-nilai moral dalam novel Ayat-Ayat Cinta karya Habiburrahman El Shirazy. Hasil análisis data menunjukkan nilai moral dalam Novel Ayat-Ayat Cinta meliputi nilai kejujuran, menjadi diri sendiri, sikap bertanggung jawab, nilai kemandirian, nilai kerendahan hati, dan nilai atau sikap kritis. Nilai-nilai tersbut menunjukkan adanya pesan moral yang sangat tinggi sehingga menjadikan novel tersebut menjadi novel yang sangat dinikmati pembacanya. Selain itu, masih ada beberapa nilai moral yang ada dalam novel AAC karya Habiburrahman El Shirasy tersebut. Nilai-nilai moral tersebut (1)) bermunajad (berdoa), (2) sikap berhati-hati, (3) ketentuan allah (takdir), (4) bertasbih, (5) bersyukur kepada allah, (6) bersikap sabar, (7) taqdir. Nilai nilai dalam novel AAC dalam bahasan ini mengacu pada baik-buruknya sebagai manusia.

Kata kunci: nilai-nilai moral, novel ayat-ayat cinta.

Abstract: The descriptive analysis approach is used in this study. Meanwhile, the purpose is to define and examine the moral principles of Habiburrahman El Shirazy's novel Ayat-Ayat Cinta (AAC). The AAC's moral principles, according to the data analysis, include honesty, being oneself, being responsible, the value of independence, the value of humility, and the importance of a critical perspective. These qualities point to a strong moral message throughout the work, making it one that readers will love. In addition, the novel AAC has a number of moral ideals. (1) bermunajad (pray), (2) cautious attitude, (3) Allah's provisions (destiny), (4) exalt, (5) thank God, (6) be patient, and (7) destiny are the moral principles. The values in the AAC novel in this discussion refer to the good and bad as humans.
\end{abstract}

Keywords: Moral values, Ayat-Ayat Cinta Novel

Citation: Wibowo, A., Wuryantoro, A., \& Ricahyono, S. (2022). Nilai-Nilai Moral dalam Novel Ayat-Ayat Cinta Karya Habiburrahman El Shirazy. Wewarah: Jurnal Pendidikan Multidisipliner, 1(1), 42 - 54.

\section{$(\mathrm{cc}) \mathrm{Br}^{\mathrm{C}}$}

Published by Program Pascasarjana Universitas PGRI Madiun. This work is licensed under the Creative Commons AttributionNonCommercial-ShareAlike 4.0 International License. 


\section{PENDAHULUAN}

Karya sastra merupakan ungkapan kehidupan melalui bahasa yang bersifat rekaan dan dapat memberikan pengalaman baru bagi pembacanya. Pengalaman baru yang diperoleh pembaca itu dapat memperkaya kehidupan batin sehingga pembaca dapat menilai lebih dari kegiatan membaca itu. Berbicara tentang sastra kita tidak lepas dari unsur fungsi dan manfaatya. Menurut Saryono (2009: 1617) sastra bukan sekedar artefak (barang mati), tetapi sastra merupakan sosok yang hidup. Sebagai sosok yang hidup, sastra berkembang dengan dinamis menyertai sosok-sosok lainnya, seperti politik, ekonomi, kesenian, dan kebudayaan. Sastra dianggap mampu menjadi pemandu menuju jalan kebenaran karena sastra yang baik adalah sastra yang ditulis dengan penuh kejujuran, kebeningan, kesungguhan, kearifan, dan keluhuran nurani manusia. Sastra yang baik tersebut mampu mengingatkan, menyadarkan, dan mengembalikan manusia ke jalan yang semestinya, yaitu jalan kebenaran dalam usaha menunaikan tugas-tugas kehidupannya

Salah satu karya sastra dalam bentuk novel yang sangat fenomenal pada saat ini adalah novel yang berjudul Ayat-Ayat Cinta (selanjutnya disebut AAC) karya Habiburrahman El Shirazy. Wulandari (2014:563) menyatakan bahwa Novel Ayat-Ayat Cinta merupakan novel karya Habiburrahman El Shirazy yang terbit pada tahun 2004 dan bisa dikatakan sangat popular. Novel Ayat-Ayat Cinta ini bertemakan cinta dan perjuangan dalam melawan ketidakadilan. Novel AAC merupakan salah satu novel religius yang sangat berbeda dengan novel yang lain. Perbedaan dengan novel lain bahwa novel AAC selain menyajikan bentuk novel pada umumnya juga mencantumkan beberapa ayat Al Quran, Al Hadis dan sumber-sumber yang digunakan dalam memaparkan masalah dalam ceritanya. Nilai-nilai Al Quran dalam bentuk fiqih atau hukum Islam lebih tampak mendominasi novel AAC . Kedalaman nilai moral mengakibatkan novel ini dipandang sebagai novel yang berkualitas karena selain memberikan hiburan bagi pembacaanya juga menunjukkan nilai-nalai moral yang dikemas dalam bahasa yang sederhana dan mudah dipahami oleh pembacanya.

Pada sisi yang lain, novel AAC adalah sebuah novel yang secara dedaktis bisa dijadikan salah satu bahan atau materi pembelajaran pada anak didik. Kekuatan nilai moral yang ada dalam AAC merupakan sebuah nilai tersendiri bagi para guru untuk menjadikan novel AAC sebagai bahan pembelajaran. Kehalusan sikap tokoh yang senantiasa mengedepankan nilai moral dalam setiap langkahnya bisa dijadikan tauladan bagi anak didik di sekolah. Dengan suatu harapan dengan tercapainya pesan moral yang ada dalam AAC pada diri siswa setidaknya akan mampu dijadikan tolak ukur siswa dalam bertindak.

Pada abad 21 nilai moral sudah tidak lagi menjadi masalah yang serius dalam kehidupan sehari-hari. Hal ini sebagaimana dalam beberapa kasus video porno, ternyata menjadi hal biasa dan tidak lagi menjadi masalah tabu mesikpun hal tersebut menunjukkan masalah moral dan etika. "Meskipun pemahaman yang dianggap benar oleh masyarakat luas selama ini, bahwa kasus tersebut dianggap sebagai kasus asusila yang kemudian soal nilai moral dan etika menjadi sorotan utama," katanya saat dihubungi Tribunnews, Selasa (29/12/2020).

Pada sisi yang lain, nilai moral selama ini juga bukan hanya ditunjukkan oleh orang yang berpendidikan rendah bahkan mereka yang berpendidikan tinggi dengan jabatan yang tinggi juga menjadi bagian dari tidak pentingnya moral itu sendiri. Korupsi kini telah menjadi hal yang dianggap biasa dan seakan tidak lagi terkait dengan nilai moral dan etika. Padahal moral merupakan tata cara dalam kehidupan, adat istiadat atau kebiasaan yang digunakan dalam tumbuh kembang individu atau kelompok sosial untuk mencapai kematangan. Moral bisa mengendalikan tingkah laku anak yang beranjak dewasa (remaja) sehingga ia tidak melakukan hal-hal yang bertentangan dengan pandangan masyarakat. Di sisi lain tiadanya moral sering kali dituding sebagai faktor penyebab meningkatnya kenakalan remaja (Sarwono, 2010: 25).

Rendahnya nilai moral yang dtunjukkan oleh publik figur dengan video pornonya dan juga prilaku korup oleh pejabat yang berpendidikan dan jabatan tinggi menunjukkan rendahnya nilai moral dan etika dalam masayarat. Oleh karena itulah, kita saat ini telah kehilangan pedoman yang berorentasi dari tingginya nilai etika dan moral. Tidak ada lagi orang yang menjadi tuntunan dan moral.

Kekuatan moral pada novel AAC terletak pada usaha Habiburrahman El Shirazy di dalam memetik ayat Al Quran sebagai penguat pendapatnya. Ini adalah nilai yang sangat dijunjung tinggi 
manakala mampu menjadikan Al Quran untuk menentukan sebuah nilai itu baik atau buruk. Dengan adanya kutipan Al Quran dalam novel ini ternyata lebih menjadikan kebenaran yang ada tidak lagi nisbi melainkan kebenaran yang mutlak.

Selain itu, alasan peneliti meneliti novel AAC karena dalam novel tersebut banyak menyajikan nilai-nilai moral yang pantas untuk diteladani, nilai-nilai tersebut dapat menggugah hati pembaca. Dengan adanya nilai-nilai moral yang hendak disampaikan oleh pengarang dengan pesan tertulis tersebut, membuat pembaca mendapatkan masukan sekaligus arahan dalam menerapkan prilakunya.

Novel AAC menceritakan ajaran-ajaran yang baik yang harus diterapkan dalam kehidupan sehari-hari, dua di antara contohnya yaitu mengajarkan untuk saling menghormati sesama manusia dan bersabar atas segala ujian yang telah Tuhan berikan karena setiap masalah pasti ada jalan keluarnya. Novel ini juga berisikan tentang hubungan manusia dengan sang pencipta, manusia tersebut selalu mengingat Tuhannya dan selalu melaksanakan perintah Tuhannya.

Berdasarkan latar belakang yang telah dipaparkan di atas, masalah penelitian secara umum dapat dirumuskan yakni bagaimanakah nilai-nilai moral dalam novel Ayat-Ayat Cinta karya Habiburrahman El Shirazy?. Sedangkan secara khusus masalah dalam penelitian ini dapat dirumuskan yakni bagaimanakah nilai-nilai moral yang berhubungan dengan agama Islam dalam novel Ayat-Ayat Cinta karya Habiburrahman El Shirazy?

Adapun tujuan yang hendak dicapai dari penelitian ini adalah mendekripsilan dan menganalisis nilai-nilai moral dalam novel Ayat-Ayat Cinta karya Habiburrahman El Shirazy. Secara khusus penelitian ini bertujuan untuk mendeskripsikan dan menganalisis: nilai-nilai moral yang berhubungan dengan agama Islam dalam novel Ayat-Ayat Cinta karya Habiburrahman El Shirazy.

\section{Kajian Nilai Moral}

\section{Pengertian Novel}

Novel berasal dari bahasa latin novellus yang kemudian diturunkan menjadi novies yang berarti baru. Kata baru ini dikaitkan dengan kenyataan bahwa novel merupakan jenis cerita fiksi yang muncul belakangan dibandingkan dengan cerita pendek atau roman. Fiksi atau cerita rekaan dibagi menjadi tiga bentuk yaitu: cerpen, novel dan roman. Novel merupakan prosa fiksi yang menggunakan imajinasi kehidupan seseorang dan cerita yang ada di dalam novel tersebut biasanya menceritakan kehidupan sehari-hari. Diungkapkan oleh Nurgiyantoro (2015: 4), novel adalah sebuah karya imajinatif yang berbentuk fiksi kehidupan yang diidealkan dan dibangun oleh beberapa unsur pembentuknya (intrinsik), mulai dari tema, alur, penokohan, latar (setting) dan lain lain yang bersifat imajinatif

Berdasarkan uraian di atas, maka dapat disimpulkan bahwa novel merupakan salah satu jenis karya sastra berbentuk prosa. Salah satu bentuk prosa itu menyajikan sisi kehidupan manusia secara luas. Keluasannya mengakibatkan novel dikatakan sebagai narasi yang panjang. Novel sangat penting dibaca, dipelajari dan dikaji, karena sarat akan nilai-nilai kehidupan yang dapat dijadikan pedoman hidup dan menambah wawasan pembaca. Selain itu juga, novel dapat memberikan hiburan. Hiburannya akan dihadirkan melalui setiap kisah yang dihadirkan

\section{Nilai Moral}

\section{Nilai}

Nilai adalah tentang apa yang baik, benar, bijaksana dan apa yang berguna. Yang mana nilai merupakan sesuatu yang bersifat ideal, ia adalah ide atau konsep yang bersifat abstrak, tidak dapat disentuh oleh panca indera (Ghazalba, 1978:23) Nilai merupakan ukuran untuk menghukum atau memilih tindakan dan tujuan tertentu. Nilai sesungguhnya tidak terletak pada suatu benda atau peristiwa, tetapi manusia memasukkan nilai di dalamnya, jadi, barang mengandung nilai, karena subjek yang tahu dan menghargai nilai itu. Tanpa hubungan subjek atau objek, nilai tidak ada. Suatu benda ada, sekalipun manusia tidak ada. Tetapi benda itu tidak bernilai, kalau manusia tidak ada. 
Karena itu, nilai adalah cita, idea, bukan fakta. Sebab itulah, tidak ada ukuran-ukuran yang objektif tentang nilai dan karenanya ia tidak dapat dipastikan secara kaku. (Rosyadi, 2004:115)

Berdasarkan pendapat di atas maka dapat dismpulkan bahwa nilai berasal dari tuntutan manusia yang universal sifatnya dan kemudian direfleksikan dalam kebutuhan organisme, motif sosial (interaksi), dan tuntutan intitusi sosial. Ketiga hal tersebut membawa implikasi terhadap nilai sebagai sesuatu yang diinginkan. Nilai hidup sifatnya universal, ada dalam setiap negara, budaya, maupun agama.

\section{Nilai Moral}

Moral adalah kelakuan yang sesuai ukuran (nilai-nilai) masyarakat yang timbul dari hati dan bukan paksaan dari luar, yang disertai pula oleh rasa tanggung jawab atas kelakuan (tindakan) tersebut. Tindakan ini haruslah mendahulukan kepentingan umum daripada kepentingan pribadi. Dalam Kamus Besar Bahasa Indonesia bahwa moral merupakan ajaran tentang baik buruk perbuatan dan kelakuan mengenai akhlak, budi pekerti, kewajiban, dan sebagainya (Suharso dan Ana Retnoningsih, 2009: 327)

Kesimpulannya moral merupakan semua tindakan baik dan tindakan buruk pada diri manusia yang terbentuk karena sebuah kebiasan, sedangkan etika merupakan ilmu pengetahuan mengenai asas-asas atau norma. Jadi kebisaan baik dan buruk itulah yang memberntuk moral baik dan moral buruk, oleh sebab itu sebuah kebiasan akan menjadi mengkristal atau membentuk moral seseorang.

\section{METODE PENELITIAN}

\section{Pendekatan Penelitian}

Penelitian ini menggunakan metode deskriptif analisis yang menggunakan pendekatan kualitatif, dengan ciri-ciri (1) menggunakan latar alamiah sebagai sumber data langsung dan sebagai instrumen utama, (2) bersifat deskritif, (3) lebih memperhatikan proses daripada hasil, (4) menganalisis data secara induktif, dan (5) makna merupakan perhatian utama Lincoln dan Guba (dalam FX Sulardi, 2001: 17) berpendapat bahwa karakteristik penelitian kulitatif adalah (1) naskah dan dokumen tercetak dipandang bersifat ilmiah (natural setting), peneliti tidak melakukan perubahan atau rekayasa terhadap naskah, (2) naskah dipandang sebagai sumber data langsung yang berupa dukumen dan peneliti sebagai instrumen kunci secara hermeneutis dapat memahami naskah, (3) pemaparan dan pembahasan bersifat deskritif, (4) lebih mengutamakan proses daripada hasil, (5) analisis data secara induktif, (6) makna menjadi perhatian utama, (7) desain bersifat sementara, (8) pengambilan sampel secara purposif, (9) hasil yang dinegosiasikan dengan pakar yang relevan, dan (10) teori dasar. Penelitian kualitatif lebih tertarik pada hasil yang bermakna universal artinya hasil penemuan kualitatif tidak hanya dapat digeneralisasikan pada latar subtantif yang sama tetapi juga pada latar lainnya.

\section{Tempat dan Waktu Penelitian}

Penelitian yang berjudul "Nilai-Nilai Moral dalam Novel Ayat-Ayat Cinta (AAC) karya Habiburrahman El Shirazy ini merupakan penelitian kualitatif yang bersifat deskriptif. Berdasarkan hal tersebut, penelitian ini bersifat dinamis, sehingga tidak terikat oleh tempat penelitian. Selanjutnya, penelitian ini dilaksanakan selama enam bulan, dimulai dari bulan Juli 2021 hingga bulan Desember 2021. Kegiatannya meliputi persiapan, pengumpulan data, analisis data, dan penyusunan laporan penelitian. Sesuai karakter penelitian kualitatif, waktu dan kegiatan penelitian bersifat fleksibel.

\section{Data dan Sumber Data}

Data penelitian adalah masalah atau hal-hal atau sasaran yang akan diteliti. Dengan adanya masalah menyebabkan orang-orang terpancing untuk berfikir dan tergoda untuk melakukan penelitian untuk menemukan jawaban tentang sesuatu atau menemukan suatu fenomena yang ditemukan dalam kehidupan. Sumber data primer dalam penelitian ini adalah novel AAC karya Habiburrahman El 
Shirazy. Sumber data sekunder adalah buku-buku, karya tulis atau jurnal dari media internet maupun media masa. Sumber data sekunder berfungsi sebagai sumber pustaka yang digunakan dalam kajian pustaka dan referensi teori-teori untuk mendukung analisis atau penelitian.

\section{Teknik Pengumpulan Data}

Teknik pengumpulan data yang digunakan dalam penelitian ini adalah teknik analisis dokumen. Dokumen bisa dikumpulkan dan diklarifikasikan, selanjutnya untuk dianalisis menurut kriteria yang sudah ditetapkan. Kriteria dimaksud adalah hal-hal yang berhubungan dengan apa yang sedang diteliti.

\section{Teknik Analisis Data}

Analisis data adalah upaya yang dilakukan dengan jalan bekerja dengan data, mengorganisasikan data, memilah-milahnya menjadi satuan yang dapat dikelola, mensintesiskannya, mencari dan menemukan pola, menemukan apa yang penting dan apa yang dapat dipelajari, dan memutuskan apa yang dapat diceritakan kepada orang lain (Moleong, 2000: 248).

Data utama yang dalam penelitian adalah novel novel AAC karya Habiburrahman El Shirazy. Teknik analisis data yang digunakan adalah analisis isi (content analysis). Analisis isi (content analysis) adalah penelitian yang bersifat pembahasan mendalam terhadap isi suatu informasi tertulis atau tercetak dalam media massa (Andre Yuris, 2009: 1). Analisis data dalam penelitian ini akan membahas secara mendalam mengenai nilai-nilai sosial dalam pembentukan karakter siswa.

\section{Teknik Keabsahan Data}

Pemeriksaan terhadap keabsahan data pada dasarnya, selain digunakan untuk menyanggah balik yang dituduhkan kepada penelitian kualitatif yang mengatakan tidak ilmiah, juga merupakan sebagai unsur yang tidak terpisahkan dari tubuh pengetahuan penelitian kualitatif (Moleong, 2000:320).

Keabsahan data dilakukan untuk membuktikan apakah penelitian yang dilakukan benar-benar merupakan penelitian ilmiah sekaligus untuk menguji data yang diperoleh. Uji keabsahan data dalam penelitian kualitatif meliputi uji, credibility, transferability, dependability, dan confirmability (Sugiyono, 2007:270).

\section{Tahap-tahap Penelitian}

Bogdan dan Biklen (1982), Lincoln dan Guba (dalam Moleong, 2000: 6) menyatakan bahwa data yang terkumpul dalam penelitian kualitatif berupa katakata, gambar dan bukan angka-angka. Dengan demikian laporan penelitian akan berisi kutipan-kutipan data untuk memberi gambaran penyajian laporan tersebut. Penelitian yang bersifat kualitatif memiliki karakteristik: Pertama, datanya bersifat lunak dan alamiah. Kedua, sifat desain yang digunakan fleksibel. Ketiga, sifat penelitianya dokumenter dan secara khusus pada dokumen karya seni. Keempat, proses penelitiannya terlepas dari kondisi-kondisi yang bersifat eksperimen. Kelima, prosedur analisis datanya cenderung menggunakan kata-kata daripada angka-angka, keenam, proses penelitianya bersifat induktif.

\section{HASIL PENELITIAN}

\section{Struktur Novel AAC}

Untuk mengetahui struktur novel AAC maka pendekatan yang digunakan adalah pendekatan strukturalisme yang akan digunakan untuk menguraikan unsur-unsur intrinsik yang membangun novel AAC. Adapun unsur-unsur instrinsik novel AAC diantaranya (1) tema, Tema cinta yang diangkat dalam novel AAC mencakup: (a) cinta manusia terhadap Tuhan dan Rasul-Nya; (b) cinta seorang lelaki terhadap seorang perempuan; dan (c) cinta antarumat manusia. Berikut penjabaran cinta-cinta tersebut. (2) Tokoh dan Penokohan, meliputi Fahri, Maria, Aisha, Noura, Nurul, Syaikh Ahmad Taqiyyuddin, syaikh Utsman Abdul Fattah, Bahadur Gounzouri, Tuan Boutros Rafael Girgis, Madam 
Nahed, Yousef, teman-teman Fahri satu flat (Rudi, Hamdi, Syaiful, Mishbah), Eqbal Hakan Erbakan, Sarah, Prof. Dr. Abdul Rauf Mansour, Ismail, Ahmad, Haj Rashed, Marwan, Prof. Dr. Abdul Gafar Ja'far, ridha Sahata, Hosam, Maghdi, Elena Hashim, Polisi, Tuan Adel, Madame Yasmin, Suzan, dan Mona. (3) Alur, secara umum pengarang menggunakan alur maju atau progresif. Namun pada penjalinan cerita, pengarang tidak ha nya mengisahkan cerita berjalan ke masa depan saja namun kadang juga kembali ke masa lalu. (4) latar, latar adalah keterangan yang melukiskan situasi yang berkaitan dengan tempat, waktu, dan keadaan sosial terjadinya cerita. Latar dalam kisah ini dibagi menjadi tiga, yaitu latar tempat, waktu, dan sosial. (5) Sudut Pandang, pada novel $A A C$ pengarang memposisikan dirinya sebagai tokoh pelaku utama. Pada novel tersebut terlihat bahwa sudut pandang yang digunakan pengarang dalam bercerita adalah sudut pandang orang pertama pelaku utama. (6) Bahasa, latar ajaran islam yang kuat mempengaruhi bahasa yang digunakan sebagai media pengarang menyampaikan gagasannya. Hal ini tampak pada banyaknya doa-doa yang diangkat ke dalam cerita AAC.

\section{Nilai Moral Novel AAC}

Pesan moral merupakan bagian yang penting untuk kita dapat, agar menambah pengetahuan tentang nilai kehidupan. Dalam kehidupan ini bukan hanya sekerdar mendapatkan pengethuan tentang intelektula saja, tetapi juga pengetahuan tentang moral, karena bagaimanapun moral adalah variabel yang harus pertama kita miliki dalam kehidupan kita. Oleh sebab itu, pengetahuan moral dalam kehidupan manusia merupakan hal yang saling membutuhkan. Beberapa pesan moral menurut Suseno (2007: 142-149) meliputi sebagai berikut ini.

1. Jujur

Jujur berarti seia-sekata, apa yang diungkapkan sesuai dengan fakta atau sesuai dengan kenyataan. Sikap jujur atau fair akan menumbuhkan kepercayaan orang lain kepada kita sendiri. sikap jujur adalah sikap yang tidak menentang suara hatinya atau terhadap keyakinannya. Sikap jujur tidak memandang adanya perasaan minder atau takut untuk bersikap jujur, akan tetapi keyakinan yang mantap tanpa menutupi sebuah hal yang kurang baik dalam kehidupan kita. Keyakinan hidup untuk tidak menentang hati nurani pada diri manusia merupakan dasar bahwa manusia merupakan mahluk yang etis, artinya sejak lahir manusi itu adalah baik, oleh sebab itu sikap jujur perlu dikembangkan lagi dalam kehidupan sehari-hari. Sedangkan nilai-nilai kejujuran dalam novel AAC, diantara sebagai berikut

Kalau tak ingat, bahwa tidak semua orang diberi nikmat belajar di bumi para nabi ini.

Kalau tidak ingat, bahwa aku belajar di sini dengan menjual satu-satunya sawah warisan dari kakek. (AAC:21)

2) Menjadi diri sendiri

Menjadi diri sendiri yaitu tidak mudah terpengaruh oleh mode yang bisa merugikan diri kita sendiri, sikap menghayati dan menunjukan diri sesuai dengan keasliannya, karakter yang kuat dan matang sesuai dengan kebenaran. Sikap menjadi diri sendiri merupakan keyakinan yang kuat tanpa terpengaruh mode dan perkembangan jaman, artinya kita mempunya pendirian yang kuat terhadap suatu kebenaran. Sedangkan nilai-nilai menjadi diri sendiri diantaranya sebagai berikut.

Tak bisa dibayangkan betapa kacaunya di luar sana. Panas disertai gulungan debu yang berterbangan. Suasana yang jauh dari nyaman. Namun niat harus dibulatkan. Bismillah tawakkaltu 'ala Allah, pelan-pelan kubuka pintu apartemen (AAC:18)

3) Bertanggung jawab

Bertanggung jawab berarti kesediaan dalam melakukan apa yang harus dilakukan dengan sebaik mungkin. Bertanggung jawab dilakukan tanpa adanya beban untuk menyelesaikannya, demi tugas itu sendiri. Sikap tanggung jawab dalam pelakasanaannya tanpa adanya rasa malas, takut atau malu untuk melakukan tanggung jawab yang akan kita lakukan. Sikap tanggung jawab merupakan hal yang sangat penting dari bagian hidup kita, karena sikap tanggung jawab bukan hanya melakukan apa yang kita lakukan untuk diri kita, tetapi juga demi semua kalangan yang berkaitan dengan kita maupun semua pihak yang wajib kita melakukan tangung jawab 
dalam segala aspek. Adapun nilai-nilai tanggungjawab dalam novel AAC diantaranya sebagai berikut,

Jadwalku mengaji pada Syaikh yang terkenal sangat disiplin itu seminggu dua kali. Setiap Ahad dan Rabu. Beliau selalu datang tepat waktu. Tak kenal kata absen. Tak kenal cuaca dan musim. Selama tidak sakit dan tidak ada uzur yang teramat penting, beliau pasti datang. Sangat tidak enak jika aku absen hanya karena alasan panasnya suhu udara (AAC:16)

4) Kemandirian

Kemandirian adalah kekuatan batin untuk mengambil sikap moral sendiri dan bertindak sesuai norma. Kekuatan untuk tidak mau berkongkalikong dalam suatu urusan atau permainan yang kita sadari tanpa sikap jujur, korup atau melanggar keadilan. Kemandirian merupakan sikap yang seseorang memiliki pendirian dalam bertindak, tanpa mengikuti arus angin yang kurang baik. Di kehidupan ini kita membutuhkan sikap kemandirian, agar kita kedepannya kita bisa hidupa dalam lingkungan tanpa harus mengerjakan seseuatu dengan bantuan orang lain. Pada dasarnya sikap mandiri melatih diri kita untuk bisa hidup dalam keadaan lingkungan seperti apapun, agar keberlangsungan hidup kita menjadi lebih baik dan mandiri dalam kehidupan sehari-hari. Adapun nilai-nilai kemandirian dalam novel AAC diantaranya sebagai berikut

Malam ini, sementara teman-teman terbang ke zaman Ashabul Kahfi, mereka berdialog dengan pemuda-pemuda pilihan itu, aku malah berlayar di lautan kata-kata yang disusun Ibnu Qayyim. Aku harus membaca dengan teliti dan mengedit tulisan sebanyak 357 halaman. Tengah malam aku kelelahan. Aku istirahat dengan melakukan shalat (AAC:164).

5) Keberanian moral

Keberanian adalah kesetiaan terhadap suara hati, keberanian untuk mempertahankan sikap yang diyakini sebagai suatu kewajiban tanpa melanggar nilai-nilai moral walau harus mengambil resiko konflik. Sikap keberanian moral memiliki keutamaan, yaitu tidak mudah mundur dalam melakukan tanggung jawab tanpa melanggar norma dalam kehidupan. Sikap keberanian moral pada era sekarang sangat dibutuhkan untuk memberanikan diri dalam segala tindakan yang tidak adil dalam kehidupan kita, maupun dalam pemerintah yang sering kita sorot kinerjanya sebagai contoh masyarakat. Sedangkan nilai-niai keberanian moral dalam AAC diantaranya sebagai berikut.

Sebab hanya Allah saja yang berhak menentukan siapa-siapa yang patut diberi hidayah. Abu Thalib adalah paman nabi yang mati-matian membela dakwah nabi. Cinta nabi pada beliau sama dengan cinta nabi pada ayah kandungnya sendiri. Tapi masalah hidayah hanya Allah yang berhak menentukan. Nabi tidak bisa berbuat apa-apa atas nasib sang paman yang amat dicintainya itu. Juga hidayah untuk Maria. Hanya Allah yang berhak memberikannya (AAC:27)

6) Kerendahan hati

Kerendahan hati ialah suatu sikap yang tidak berlebihan atau menyombongkan diri, melainkan melihat diri sesuai dengan kenyataannya, tetapi bukan berarti merendahkan diri. kerendahan hati bukan berarti sikap mengalah, orang yang tidak berani, dan tidak mampu membela suatu pendirian, akan tetapi sikap kerendahan hati memberikan pemahaman bahwa kita sebagai manusia mempunyai kekuatan terbatas, akal yang terbatas, setiap usaha yang kita lakukan bisa gagal dan tidak selalu tercapai dengan apa yang kita inginkan. Melalui sikap kerendahan hati, kita menjadi tidak sombong dan membangkakan diri dengan kelebihan yang kita miliki, yang sebernarnya justru menjadikan kita sombong. Oleh karena itu membutuhkan sikap kerendahan hati dalam kehidupan kita, agar kita menyadari dan mensyukuri semua kelebihan kita untuk digukan dalam hal yang positif bukan untuk dipamerkan. Adapun nilai kerendahan hati dalam novel AAC diantaranya sebagai berikut.

Meskipun masih muda, namun kedalaman ilmu agama dan kefashihannya membaca serta mentafsirkan Al-Qur'an membuat masyarakat memanggilnya "Syaikh". Kerendahan hati, dan komitmennya yang tinggi membela kebenaran membuat sosoknya dicintai dan dihormati semua lapisan masyarakat Hadayek Helwan dan sekitarnya (AAC:31) 
7) Kritis

Sikap kritis yaitu suatu tindakan untuk mengoreksi, memberikan saran baik terhadap segala kekuatan, kekuasan dan wewenang yang dapat merugikan kehidupan individual maupun masyarakat. Sikap kritis pada dasarnya memberikan suatu saran yang bermanfaat pada seseorang maupun untuk diri kita sendiri agar kedepannya menjadi lebih baik dalam bertindak dikehidupan sehari-hari. Semakin kita kritis dengan sikap pada diri kita maupun segala hal yang melanggar moral kita juga berhak memberikan kritik untuk memperbaiki hal yang bisa melanggar norma-norma kehidupan. Sedangkan nilai-nilai yang bersifat kritis dalam novel AAC diantaranya sebagai berikut.

Fahri, aku geli sekali mendengar perkataan doktor dari Sorbonne itu. Dia itu orang Arab, juga muslim, tapi bagaimana bisa mengatakan hal yang stupid begitu. Aku saja yang Koptik bisa merasakan betapa indahnya Al-Qur'an dengan alif laam miim-nya (AAC:26).

Sebuah kritikan terhadap perkataan seorang doctor muslim namun seperti perkataan orang yang bodoh. Bahkan seorang kristen koptik mampu merasakan keindahan bacaan Al Qura'an. Ini menunjukkan bahwa tidak semua yang berpendidikan, semua muslim mampu berkata dengan perkataan yang bai.

"Dan orang seperti Gamal jangan kau herankan keberadaannya di zaman yang telah kehilangan nurani kemanusiaannya seperti sekarang. Uang menjelma menjadi tuhan. Uang adalah segalanya. Demi uang begundal seperti Gamal siap mengerjakan apapun saja," sahut Haj Rashed. (AAC:339)

Kritikan yang tajam juga diarahkan pada para masyarakat yang beruang atau memiliki uang yang banyak. Meraka dapat berbuat apa saja dengan uangnya. Bahkan uang dapat menjilma menjadi tuhan yang bisa menentukan segalanya miskipun mengorbankan orang kecil atau orang lain dengan dholim.

\section{Nilai-Nilai Moral yang lain.}

Selain nilai-nilai moral yang diuraikan berdasarkan pendapat pesan moral menurut Magniz Suseno maka masih ada beberapa nilai moral yang ada dalam novel AAC karya Habiburrahman El Shirasy tersebut. Nilai-nilai moral tersebut (1)) bermunajad (berdoa), (2) sikap berhati-hati, (3) ketentuan allah (takdir), (4) bertasbih, (5) bersyukur kepada allah, (6) bersikap sabar, (7) taqdir. selengkapnya dari nilai moral tersebut, akan dijelaskan senagai berikut.

1. Bermunajad (Berdoa) kepada Allah.

Berdo'a merupakan cara berdialog dengan Allah; juga merupakan ciri utama yang membedakan orang yang beriman dari orang musyrik. Berdo'a bisa dijadikan sebagai alat ukur keimanan seseorang kepada Tuhannya. Akan tetapi, haruslah dipahami bahwa Allah tidak harus mengabulkan semua yang diinginkan dari-Nya.

Cara berdo'a diantaranya dengan kerendahan hati dan suara yang lembut, keihlasan, dalam hati kita berharap, namun takut pada Allah, serta dengan kesungguhan. Bentuk dan adap berdoa dalam novel $A A C$ memang sangat banyak, di antaranya ketika tokoh Fahri akan berpergian. Petikan tersebut adalah:

Aku sedikit ragu mau membuka pintu. Hatiku ketar-ketir. Angin sahara terdengar mendesaudesau. Keras dan kacau. Tak bisa dibayangkan betapa kacaunya di luar sana. Panas disertai gulungan debu yang beterbangan. Suasana yang jauh dari nyaman. Namun niat harus dibulatkan. Bismillah tawa-kkaltu 'ala Allah,' pelan-pelan kubuka pintu apartemen. (ACC:18)

Dalam novel $A A C$ dapat dijumpai beberapa adab berdoa, cara berdoa, doa yang diajarkan rosulullah dan kalimat-kalimat doa yang lain. Hal tersebut menujukkan bahwa $A A C$ sebagai novel juga menyajikan niali-nilai yang bermanfaat bagi pembacanya.

2. Sikap berhati-hati 
Pengarang, tampak sangat konsen dalam mensyaratkan sikap hati-hati dalam bertindak baik yang menyangkut masa sekarang maupun masa yang akan datang. Hal tersebut tampak pada kutipan di bawah ini.

Ah, kalau tidak ingat bahwa kelak akan ada hal yang lebih panas dari hari ini dan lebih gawat dari hari ini. Hari ketika manusia digiring di padang Mabsyar dengan matahari hanya satu jengkal di atas ubun-ubun kepala. Kalau tidak amanat akan dipertanggungjawabkan dengan pasti. Kalau tak ingat, bahwa masa muda yang sedang aku jalani ini akan dipertanyakan kelak. Kalau tak ingat, bahwa tidak semua orang diberi nikmat belajar di bumi para nabi ini. Kalau tidak ingat, bahwa aku belajar di sini dengan menjual satu-satunya sawah warisan dari kakek. Kalau tidak ingat, bahwa aku dilepas dengan linangan air mata dan selaksa doa dari ibu, ayah, dan sanak saudara. Kalau tak ingat bahwa jadwal adalah janji yang harus ditepati. (AAC:20-21)

Dalam kutipan tersebut tampaknya sikap hati-hati adalah sesuatu yang patut ditanamkan sejak dini. Setiap orang akan dimintai pertanggungjawabab apa yang dilakukan. Hal tersebut juga berlaku pada diri seseorang pada masa mudanya. Untuk apakah masa muda tersebut digunakan? Kebaikankah? Atau keburukan?. Itulah yang nantinya akan ditanyakan dan dipertanggungjawabkan dihadapan Allah. Semua tidak akan lepas dari pantaulan Allah sekaligus akan dimintai pertanggungjawabannya. Inilah sebenarnya makna dari sebuah kehati-hatian dalam bertindak dari masa ke masa.

3. Pertolongan Allah

Sikap percaya bahwa sesuatu adalah kehendak Allah adalah sikap ketawakalan seseorang di dalam menerima apa adanya. Tidak ada satu manusia pun di dunia ini yang bisa memastikan segala sesuatu. Hal tersebut menunjukkan kepada manusia bahwa manusia itu manusia yang lemah, terbatas, tak berkemampuan dalam menentukan segala sesuatu. Nilai pertolongan Allah ini tampak pada novel $A A C$ dalam kutipan di bawah ini.

Sebab, hanya Allah saja yang berhak menentukan siapa-siapa yang patut diberi hidayah. Abu Thalib adalah paman Nabi yang mati-matian membela dakwah Nabi. Cinta Nabi pada beliau sama dengan cinta Nabi pada ayah kandungnya sendiri. Tapi masalah hidayah hanya Allah yang berhak menentukan. Nabi tidak bisa berbuat apa-apa atas nasib sang paman yang amat dicintainya itu. Juga hidayah untuk Maria. Hanya Allah yang berhak memberikannya. (AAC:27)

Dalam kutipan tersebut tampaknya ingin menunjukkan pada pembaca bahwa segala sesuatu yang terjadi di dunia ini semua ditentukan Allah. Dan Allah bebas dalam menentukan segala sesuatu. Allah berhak menetukan menentukan siapa-siapa yang patut diberi hidayah. Bahkan untuk menunjukkan kuasa penuh Allah tersebut disampaikan bahwa Nabi Muhammad Saw. Sebagai kekasih Allah, hamba yang dijamin masuk surga-Nya, penerima wahyu Allah, hamba yang pernah berhadapan dengan Allah sendiri tidak bisa memberi hidayah kepada pamannya sendiri yang telah banyak membantu perjuangan nabi. Oleh karena itu, manusia tidak bisa memberikan jaminan kepastian kepada siapaun kecuali Allah.

4. Bertasbih Memuji Allah

Dalam $A A C$ tampaknya pengarang memberikan teladan yang berupa bentuk tasbih atau ingat kepada Allah melalui prilaku tokohnya. Contoh bentuk ingat dan pujian pada Allah di anataranya pada kutipan di bawah ini.

Hembusan udara sejuk yang dipancarkan lima AC dalam masjid menyambut ramah. Alhamdulillah. Nikmat rasanya jika sudah berada di dalam masjid. Puluhan orang sudah berjajar rapi dalam shaf shalat jamaah. Kuletakann topi dan tas cangklongku di bawah tiang dekat aku berdiri di barisan shaf kedua. Kedamaian menjalari seluruh syaraf dan gelegak jiwa begitu kuangkat takbir. Udara sejuk yang berhembus terasa mengeluselus leher dan mukaku. juga mengusap keringat yang tadi mengalir deras. Aku merasa tenteram dalam elusan kasih sayang Tuhan Yang Maha Penyayang. Dia terasa begitu dekat, lebih dekat dari urat leher, lebih dekat dari jantung yang berdetak (AAC::30)

Alhamdulillah atau segala puji apada Allah adalah salah satu kata yang tepat untuk mengungkapkan rasa syukur atas kenikmatan yang telah diberikan. 
5. Bersyukur kepada Allah

Ungkapan rasa syukur dalam novel $A A C$ tersirat dengan jelas melalui ungkapan beberapa tokoh cerita. Di antara contoh pengungkapan syukur tersebut sebagaimana dlam kutipan berikut.

Alhamdulillah, Teman-teman sangat pengertian dan cerdas. Aku bisa langsung mandi tanpa menunggu air dingin. Ketika air menyiram seluruh tubuh, rasa segar itu susah diungkapkan dengan bahasa verbal. Habis mandi tenaga rasanya pulih kembali (AAC::62)

Ketika dibantu teman sehingga Fahri mendapatkan kemudahan ungkapan yang disampaikan adalah Alhamdulillah 'puji syukur kehadiratAllah'. Ungkapan syukur tersebut tidak tertuju kepada teman yang membantu melainkan ditujukan kepada Allah. Teman atau orang lain hanyalah perantara sedangkan penentu adalah Allah.

6. Sikap Sabar

Nilai moral yang ada di dalam novel $A A C$ adalah sifat sabar. Manusia diciptakan dengan disertai sifat tidak sabar dan karenanya ia banyak berbuat kesalahan. Akan tetapi, agama meminta setiap orang agar bersabar karena Allah. Orang beriman, terutama, harus sabar menunggu keselamatan yang besar yang Allah janjikan. Sabar merupakan salah satu sifat penting untuk mencapai ridha Allah; itulah kebaikan yang harus diusahakan agar lebih dekat kepada Allah.

" Aku sudah tahu. Bersabarlah. Allah mencintai orang-orang yang bersabar." Jawab Aisha.

Aku menghela nafas panjang. Aku ingin shalat malam (AAC:242)

Ajakan untuk bersabar tercermin dalam kutipan teks tersebut. Sabar adalah bentuk dan sifat muslim ketika menghadapi permasalahan baik yang berkategori ringan maupun berat. Kesabaran adalah sebuah pintu untuk mencapai ridho Allah yang sebenarnya. Oleh karena itulah Fahri meminta sabar kepada istrinya ketika dihadapkan pada masalah yang berat.

7. Takdir

Takdir adalah ketentuan yang telah digariskan oleh Allah atas diri manusia oleh karenanya manusia hanya bisa berusaha agar takdir di akhirta lebih baik dengan takdir di dunia. Di dunia boleh saja sengsara namun di akhirat harus lebih baik. Kutipan mengenai penjelasan takdir tersebut tersurat dalam kutipan berikut.

Takbir dan hamdalah bergemuruh di ruang pengadilan itu dilantunkan oleh semua orang yang membela dan bersimpati padaku. Seketika aku sujud syukur kepada Allah Swt. Aisha memelukku dengan tangis bahagia tiada terkira. Paman Eqbal dan Bibi Sarah tak mampu membendung airmatanya. Syaikh Ahmad dan Ummu Aiman juga sama. Nurul dan suaminya yaitu Mas Khalid datang memberi selamat. (AAC:388)

Sebagaimana dalam kutipan tersebut pengarang ingin menyampaikan bahwa apapun yang terjadi di dunia adalah sebuah takdir dari Allah. Namun, diharapkan bahwa meskipun takdir di dunia terasa berat tetapi hendaknya tidak akan terjadi berat pula jika sudah di akhirat.

\section{PEMBAHASAN}

Karya sastra merupakan salah satu cerminan nilai-nilai budaya dan tidak terlepas dari sosial budaya serta kehidupan masyarakat yang digambarkannya. Sastra menyajikan gambaran kehidupan, dan kehidupan itu terdiri atas kenyataan sosial. Dalam pengertian ini, kehidupan mencakup hubungan antarmasyarakat dengan orang-orang, antarmanusia, antarperistiwa yang terjadi dalam batin seseorang (Noor, 2011:27). Dapat disimpulkan karya sastra adalah tulisan hasil imajinasi pengarang yang mengandung makna dan merupakan cerminan nilai-nilai bermasyarakat dalam memberikan gambaran suatu kehidupan.

Noor (2011:64) berpendapat moral dalam sastra biasanya mencerminkan pandangan hidup pengarang yang bersangkutan. Pandangannya tentang nilai-nilai kebenaran, dan hal itulah yang ingin disampaikan kepada pembaca. Sebuah karya sastra ditulis oleh pengarang, antara lain untuk menawarkan model kehidupan yang diidealkannya. Karya sastra mengandung penerapan moral dalam sikap dan tingkah laku para tokoh sesuai dengan pandangan tentang moral. Melalui cerita, sikap, dan tingkah laku tokoh-tokoh itulah pembaca diharapkan dapat mengambil hikmah dari pesan-pesan moral yang disampaikan atau diamanatkan. 
Moral dalam sastra itu sangat berkaitan, bagaimana nilai-nilai yang terdapat dalam karya sastra dapat dipahami dan dimaknai pembaca setelah membaca karya sastra. Karya sastra mengandung penerapan moral melalui tindakan yang dilakukan oleh tokoh. Jadi dapat disimpulkan moral dalam sastra adalah suatu nilai-nilai, pesan, sikap, tindakan, dan perilaku yang disampaikan pengarang terhadap pembaca.

Nilai nilai moral dalam novel AAC dalam bahasan ini diuraikan berdasarkan pendapat Franz Magnis Suseno. Menurut Suseno (2007: 19) kata moral selalu mengacu pada baik-buruknya manusia sebagai manusia. Pengertian moral tidak hanya mengacu pada baik buruknya saja, misalnya sebagai dosen, tukang masak, pemain bulu tangkis atau penceramah, melainkan sebagai manusia yang bertanggung jawab terhadap profesinya. Bidang moral adalah bidang kehidupan manusia dilihat dari segi kebaikannya sebagai manusia. Sedangkan nilai moral dalam sastra (Suseno, 2007: 142-149) meliputi (1) Jujur, (2) Menjadi diri sendiri, (3) Bertanggung jawab, (4) Kemandirian, (5) Keberanian moral, (5) Kerendahan hati dan (7) Kritis.

Selain nilai-nilai moral yang diuraikan berdasarkan pendapat pesan moral menurut Magniz Suseno maka masih ada beberapa nilai moral yang ada dalam novel AAC karya Habiburrahman El Shirasy tersebut. Nilai-nilai moral tersebut (1)) bermunajad (berdoa), (2) sikap berhati-hati, (3) ketentuan allah (takdir), (4) bertasbih, (5) bersyukur kepada allah, (6) bersikap sabar, (7) taqdir.

Pesan moral dalam novel AAC berusaha mengajak pembaca menjunjung tinggi norma-norma moral. Mesterianti Hartati dan Adisti Primi Wulan (2016) dalam karyanya yang berjudul Analisis Nilai Moral Yang Terkandung Dalam Novel Ayat-Ayat Cinta Karya Habiburrahman El Shirazy menyatakan bahwa nilai moral yang terdapat dalam Novel Ayat-Ayat Cinta terdiri dari Pertama. moral berhubungan dengan keagamaan berkaitan dengan: melaksanakan sholat, bersyukur kepada Allah, berdoa, dan membaca al Quran. Kedua, nilai Moral berhubungan dengan masyarakat yang terdapat di dalam novel berupa: Tolong menolong sesama manusia, hormat menghormati sesama manusia, dan kasih sayang sesama manusia.

Dalam novel Sang Pencerah ditemukan nilai-nilai motral (1) nilai moral antara manusia dengan dirinya sendiri, yaitu, kejujuran, sabar, semangat, tanggung jawab, ikhlas, pantang menyerah, tegas, berani, dan rendah hati. (2) nilai moral antara manusia dengan manusia seperti sopan, peduli, tolong menolong, saling berbagi, menempati janji, menyemagati dan memotivasi, bekerja sama, dan bersosialisasi. (3) Nilai moral Antara manusia dengan alam terdiri seperti naasionalisme, menjaga kelestarian alam. (4) nilai moral antara manusia dengan Tuhan yaitu bersyukur, taat beribadah dan berperasangka baik kepada Tuhan (Firwan, 2017).

Nilai-nilai moral yang ditemukan dalam novel "Surat Kecil Untuk Tuhan" karya Agnes Davonar adalah hubungan manusia dengan diri sendiri, hubungan manusia dengan manusia lain dalam lingkup sosial dan lingkungan alam dan hubungan manusia dengan Tuhan (2017). Nilai-nilai moral yang ditemukan dalam Dwilogi Novel Saman dan Larung karya Ayu Utami adalah: 1) yang terkait dengan hubungan manusia dengan Tuhan yang meliputi rasa takut akan Tuhan dan tidak percaya atau ragu akan Tuhan; 2) yang terkait dengan hubungan manusia dengan Masyarakat yang terdiri dari jujur terhadap orang lain, pertalian persahabatan, tolong-menolong, kewajiban mengabdi kepada orang lain atau melaksanakan kewajiban dan perintah, saling mengenal, dan penyimpangan seksual; 3) yang terkait dengan hubungan manusia dengan Individu (diri sendiri) seperti pengendalian diri, takut berdosa atau bersalah, senang hidup sederhana, berani mengakui dosa, percaya diri, berlaku adil, dan bertindak hati-hati (Muplihun, 2016).

Nilai-nilai moral yang terkandung dalam novel Peter karya Risa Saraswati meliputi: kasih sayang orang tua, nasionalisme, percaya diri, bersahabat, menghargai orang lain, sopan santun, peduli lingkungan, peduli sesama, religius, menghargai tamu (Rahmawati \& Achsani, 2019).

Hasil analisis tersebut menunjukkan bahwa sikap moral pada dasarnya merupakan perilaku yang terpuji sebagai manusia. Analisis terhadap nilai moral akan memberikan manfaat bagi pembaca khususnya para pendidik. Hal tersebut sesuai dengan pendapat Waluyo (2011) yang menyatakan bahwa salah satu kriteria karya sastra harus bermuatan moral dan nilai-nilai edukatif. Pesan-pesan moral dan edukatif yang terkandung dalam novel yang sangat jarang dijumpai di novel-novel lain ini diharapkan dapat di contoh dan diteladani oleh peserta didik dalam kehidupan sehari-hari. Sehingga dengan mengimplementasikan apa yang sudah dibaca dalam novel, usaha pendidikan untuk membentuk peserta didik yang bermoral dapat terealisasikan dengan baik 


\section{SIMPULAN}

Berdasarkan hasil-hasil penemuan sebagaimana diuraikan di atas maka dapat disimpulkan bahwa:

1. Nilai Moral Novel Ayat-Ayat Cinta

Pesan moral merupakan bagian yang penting untuk kita dapat, agar menambah pengetahuan tentang nilai kehidupan. Dalam kehidupan ini bukan hanya sekerdar mendapatkan pengethuan tentang intelektula saja, tetapi juga pengetahuan tentang moral, karena bagaimanapun moral adalah variabel yang harus pertama kita miliki dalam kehidupan kita. Oleh sebab itu, pengetahuan moral dalam kehidupan manusia merupakan hal yang saling membutuhkan. Beberapa nilai moral dalam Novel Ayat-Ayat cinta meliputi nilai kejujuran, menjadi diri sendiri, sikap bertanggung jawab, nilai kemandirian, nilai kerendahan hati, dan nilai atau sikap kritis. Nilai-nilai tersbut menunjukkan adanya pesan moral yang sangat tinggi dalam novel Ayat-Ayat Cinta sehingga menjadikan novel tersebut menjadi novel yang sangat dinikmati pembacanya,

2. Nilai-Nilai Moral yang lain.

Selain nilai-nilai moral yang diuraikan berdasarkan pendapat pesan moral menurut Magniz Suseno maka masih ada beberapa nilai moral yang ada dalam novel AAC karya Habiburrahman El Shirasy tersebut. Nilai-nilai moral tersebut (1)) bermunajad (berdoa), (2) sikap berhati-hati, (3) ketentuan allah (takdir), (4) bertasbih, (5) bersyukur kepada allah, (6) bersikap sabar, (7) taqdir. Nilai nilai dalam novel AAC dalam bahasan ini mengacu pada baikburuknya manusia sebagai manusia.

\section{Saran-Saran}

Penganalisisan sebuah karya sastra tidak lepas dari referensi yang mendu-kungnya. Untuk itu, kepada Unipma, sebagai suatu lembaga pendidikan Islam handaknya juga memberi perhatian yang cukup, seperti memberikan kesempatan yang seluas-luasnya kepada mahasiswa untuk melakukan penelitian karya sastra yang memiliki muatan religius sekaligus mampu menyediakan buku-buku atau referensi yang cukup. Artinya, Unipma tidak hanya menggiring mahasiswa Pascasarjana hanya untuk melakukan penelitian tindakan kelas.

Mahasiswa Pascasarjana Unipma harus mampu menjadi pelopor generasi muda yang cinta akan nilai seni budaya bangsa sendiri. Untuk itu, wujud kepeloporan tersebut bisa diwujudkan dalam bentuk prilaku akademis yakni kemampuan dan kemauan menganalisis karya sastra karena selain sebagai pengem-bangan profesi juga secara praktis hasilnya bisa digunakan sebagai bahan ajar di sekolah.

\section{DAFTAR PUSTAKA}

Ahadiat, Endut. 2007. Teori dan Apresiasi kesusastraan. Padang : Bung Hatta University Press.

Bogdan, R.C., Biklen, S.K.1982. Qualitative research for education:anintroduction to theory and method. Boston: Allyn and. Bacon. Inc.

Budiningsih, Asri. 2008. Pembelajaran Moral Berpijak Pada Karakteristik Siswa dan Kebudayaan. Jakarta : Rineka Cipta

El Shirazy, Habiburrahman. 2004. AyatAyat Cinta. Jakarta : Republik dan Pesantren Basmala Indonesia

FX Sulardi. 2001. Nilai Dedaktis Dalam Naskah Makhutarama. Malang: Unisma

Gazalba, Sidi, 1978. Pengantar Kebudajaan sebagai Ilmu, Jakarta: Pustaka Antara.

Herlianingsing 2013. Analisis Nilai-Nilai Moral Novel Ayat-Ayat Cinta Karya Habiburrahman El Shirazy. Skrisi. Universitas Maritim Raja Ali Haji Tanjungpinang.

Mesterianti Hartati dan Adisti Primi Wulan 2016. Analisis Nilai Moral Yang Terkandung Dalam Novel Ayat-Ayat Cinta Karya Habiburrahman El Shirazy. Jurnal Pendidikan Bahasa, Vol. 5, No. 1, Juni 2016

Moleong, Lexy J.. 2000. Metodologi Penelitian Kualitatif. Bandung: Remaja Rosdakarya. 
Muhammad Firman 2017. Nilai Moral Dalam Novel Sang Pencerah Karya Akmal Nasrey Basral. Jurnal Bahasa dan Sastra Volume 2 No 2.

Muplihun, E. (2016). Nilai Moral dalam Dwilogi Novel Saman dan Larung Karya Ayu Utami. JP-BSI (Jurnal Pendidikan Bahasa dan Sastra Indonesia), 1(2), 58-64. https://doi.org/10.26737/jpbsi.v1i2.91

Rahmawati, E., \& Achsani, F. (2019). Nilai-Nilai Moral Novel Peter Karya Risa Saraswati dan Relevansinya dengan Pembelajaran Bahasa Indonesia. Lingua Franca:Jurnal Bahasa, Sastra, dan Pengajarannya, 3(1), 52-64. http://dx.doi.org/10.30651/lf.v3i1.2435

Rosyanti, S. (2017). NILAI MORAL DALAM NOVEL SURAT KECIL UNTUK TUHAN KARYA AGNES DAVONAR. DIKSATRASIA, 1(2), 182-190.

Rosyadi, Khoiron. 2004. Pendidikan Profetik, Yogyakarta : Pustaka Pelajar. Offset

Saryono. 2009. Pengantar Apresiasi Sastra. Malang: Universitas Negeri. Malang.

Siswanto, Wahyudi. 2013. Pengantar Teori Sastra. Malang: Aditya Media Publishig.

Sugiyono. 2007. Metode Penelitian Kuantitatif Kualitatif dan $R$ \& D. Bandung: Elfabeta.

Suseno, F.M. 2007. Etika Dasar Masalah-masalah Pokok Filsafat Moral. Yogyakarta: Kanisius.

Winarno Surakhmad. 1980. Pengantar Penelitian Ilmiah. Bandung : Tarsito.

Wulandari, Suci. 2014. Novel Ayat-Ayat Cinta Karya Habiburrahman El Shirazy dan Novel KasidahKasidah Cinta Karya Muhammad Muhyidin (Kajian Intertekstual dan Nilai Pendidikan). Universitas Sebelas Maret: Surakarta

Zuriah, Nurul. 2007. Pendidikan Moral dan Budi Pekerti dalam Perspektif Perubahan Mengagas platform Pendidikan Budi Pekerti secara Kontekstual dan futuristik. Jakarta: PT Bumi Aksara 